Historic, archived document

Do not assume content reflects current scientific knowledge, policies, or practices. 



\subsection{3}

n. (2)

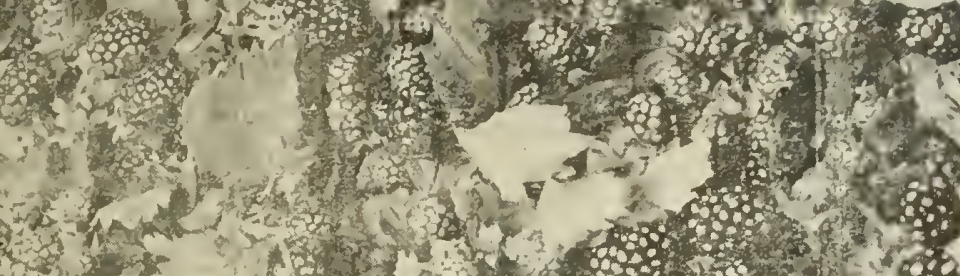

Nithon (2)

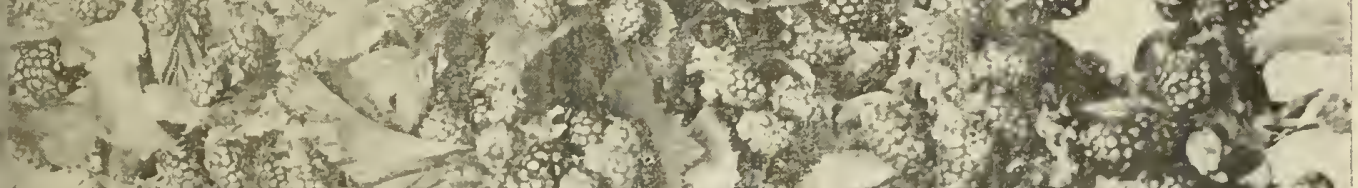
d.t.

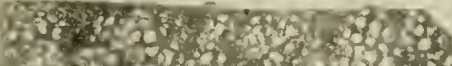

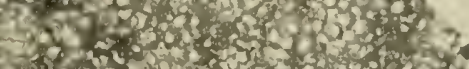

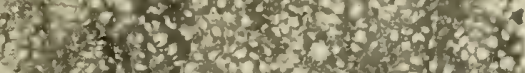

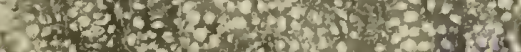
87. 6x; (6) - 4028 4. H.t.

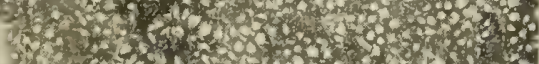
6. 37 .

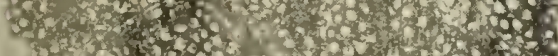

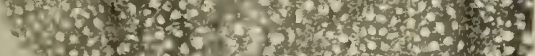

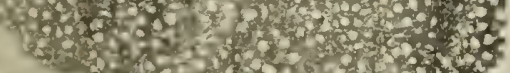

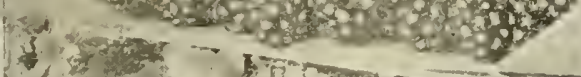
(1)

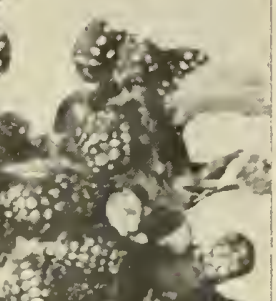





\title{
FITZGERALD'S NURSERY
}

\author{
J. E. FITzGerald, Prop \\ STEPHENVILLE, TEXAS, R. F. D. 5 \\ ERATH COUNTY
}

\section{INTRODUCTION.}

This price list is our only salesman. We are not getting out a costly catalog and making our custnmers pay for it, but we do promise to send you as good vines and trees as can be bought anywhere for the money. We make a specialty of berry vines, believing that they are one of the best crops that can be planted, not only paying a higger dividend but building up the soil.

\section{About Ourselves,}

We own an orchard here in Erath county. We have every variety of fruit or plant in bearing that we offer for sale. Wo have many kinds of peaches, plums, apples; and twenty-three varieties of Japanese persimmons. We know just what fruits will pay. It is no hear'say with us. We have made many mistakes we can tell you how to avoid.

Many Nurserymen propagate and Eell trees they never saw in bearing. At the proper season we can r.ften send samples of the fruits we grow. We have been growing all kinds of fruits here for more than rifteen years, and got our elucation in the school of hard knocks. refer you to the First National $\mathrm{As}_{\mathrm{s}}$ to our responsibility we can bank, the Farmers National bank, Cage \& Crow, bankers, any business house in Stephenville, or to the Stephenville Tribune, our leading paper.

It is impossible to estimate the profits of an orchard for home use; for aside from the money value, it is a great pleasure to have even a few trees in the back yard on a city lot. If you don't believe a mar prizes them offer to cut one down. You'd have a row with the mau of the house, the good lady, and on down to the least tot. When it comes to fruit for the market it depends on the man. One man can get more for a load of fruit than another. It is possible to make ten acres of fruit pay better than a hundred acres in cottou, and you cet the nrice on your fruit.

We will be glad to have your order for plants, and will do our best to please you. $A_{\mathrm{s}}$ we said in the beginining, we are not getting nut a big catalog and charging you with the cost, but we will sell you is good plants as anybody.

Eat fruit. Lock the medicine chest and lose the key. A dime's worth of good, ripe Japanese persimmons is worth a quarter's worth of pills. 
Plants by Mail.

Each year we send hundreds of plants by mail. In sact we make a specialty of this. We will mail roses and all tree fruits at the ach rate. of course, we can't send large trees by mail.

\section{Abcut Express.}

Only under special agreement svill we pay the express. But, if your order amounts to five dollars you can add ifify cents worth of llees and plants to your bill to help you pay the express. And if your order amounts to ten dollars, you can add one dollar's worth of trees and plants to your bill for express; and add one dollar for each additional ten dollar's worth orderad.

These offers do not anply to vegotable or potato plants.

\section{Premium Number One.}

For each five dollars' worth of plants or trees you order from us we will send you free of charge, 1 Althea, 1 Umbrella China, 1 Chestnut and one Arborvitae; 2 Coneord and 2 Niagara Grapes.

\section{Premium Number Two.}

For a ten dollar order we will send you free of charge, 5 Concord, and 5 Niagara Grapes; 2 Unworella China, 2 Althea, 2 wild Persimmons and 1 Eureka Persimmon.

\section{Premin Number Three.}

For a twenty dollar order we will send you free of charge, 10 Concord and 10 Niagara Grapes; 2 Umbreilà Chinas, 4 Althae, 2 Eureka Persimmons and 1 Tamopan.

These premiums are very valuable, and it will nay you to get your neighbors to go in with you. Get enough trees extra to pay the express and also these premiums. $B e^{\circ}$ sure and mention what premium you want.

\section{THE COLD WATER POURER.}

No matter where you jive there is lways some fellow ready io pour cold water on your plans; to say; "this is no fruit country." Up in Washington state, the finest apple country in the world, there are fellow's going around saying, "this is no apple country.' 'Up in New Fork state, where pears grow to perfection, some one is always saying, "this is no pear country." Ifter you get a berry patch planted, and the vines are literally loaded with big, black, luscious fruit, some fellow will come along; and after he has eaten about a gallon of your berries he will say, "This is no fruit country; now, back yonder' where I came from, you could raise lierries as big as goose eggs, and they tasted better than these do tiere." But these fellows help you rut, because they chill the timid fellow's plans to plant an orchard, and thus help you to get a big price for your fruit.

Maybe your place is not the best place in the world for fruit, but if vou can get a good price for what you do raise maybe you can make more money than the man who is raising fine fruit but has to sell it cheap. 


\section{A Chaptcr on "How to Plant."}

Every year I get about two liundred letters fiom people wanting to know just how to plant and what time to plant trees and vines.

From about vetober fifteenth to the midalle of April will be a goud time to plant. Howerer, I always prefered November, December, January and February as my planting months. We always pack irecs so they will reacli you in the best shape. When thry cone if you are not ready to plant them right then it is a gogd plan to heal them out. That is, take all the straw from around the roots, untie the bundles and bury them out in good, moist soil. Wet the roots good with several buckets of wat $r$. Some people set them straight up when they go to heal them out, but I always lay them nearly down. They are not so likely to dry out if the moist dirt reaches nearly to tho top,

When you go to plant trim off all broken roots. If you plant in the fall you can trim the roots back pretty close. When you sot the tree, if it is a one year old straight sprout it is hetter to eut it back to within eighteen inches of the ground. If it is a two year old cut the limbs back to within half way to the body of the tree.

There is a great difference of opinion as to how far apart to set ill kinds of trees and plants. Six feet apart each way is a good way to set blackberries. Then you san plow them both ways. Or make rows seven feet apart and set the vines three feet apart in the row. Either way is salisfactory, but they are harder to work the last way.
Sometimes we set then between Iruit tree rows. Say set them so they will be eight feet from the tree rows.

If you live where figs winter kill you can set the fig plants twelve feet apart each way. I like to sut peach trees about twenty-five ieet apart. Plum trees eighteen fect apart each way. Pear and apple frees from twenty-one to thiity feet. Such apples as Florence cral, Fellow 'Transparent and Juchess can be set fifteen feet apart each way, but the Yellow Transparent will grow up and make a large tree after a while.

Japanese persmmons can be set fifteen or twenty feet. Grape vincs are all right in rows nine feet apart and eight feet apart in the rows.

You can easily figure for jourself the number of trees to thr acre. There are 1.560 square feet in an acre. If you are going to set your trees twenty feet apart iust multiply twenty by iwenty, this will give 400 . Then divid: 33560 by 400 . You will get the num her of trees to the acle. If you aim to set your berries seven iy three feet just multiply seven by three, which will give 21; then divide 13560 by 21 .

\section{Mistakes.}

We make every effort to lave every plant true to name, but th: inost particular will sometines make mistakes, and for this reason it is inutually agreed between ourselves and our customers that we are to replace anything that prov's untrue free of charge, and that $1+$. will be held responsible no further. 
If you get two of these catalogs kindly hand one to a neighbor. I would do as much for you.

It may strike you that my price list is mighty badly ninixed up, and so $\vdots \mathrm{i}$ is. The truth 's, I wrote it rnyself. I am no journalist; don't know much grammar; was educated in the school of hard knocks. I could have employed some newspaper man to write me a price list, but I preferred to write it myself, and tell what I had learned about my plants in my own words. I have two nursery catalogs before me; one from an eastern nursery another from a nursery in Galifornia. They both have the very same reading in them and the very same pictures. This shows that they were written by the same man. Maybe the man who wrote these catalogs could not tell a San Jose scale from a weed seed. Nor an apple tree from a thorny locust. Very often the owner of a nursery lives in town, he depends on hired help to dig and pack your plants. This is the reason when an orchard comes into bearing you often do not have what you ordered.

\section{MeDonald Blackberry.}

Several years ago I bought one dozen plants of McDonald. These were accidentally planted through the middle of my Early Wonder berry patch. Thhen these berries came into bearing they were the wonder of all who saw them. The plants had sent out runners fifleen feet long, and were almost ropes of berries to the end of the vines. I gathered five gallons of fruit from a single vine that sold in a local town at fifty cents per Eallon. I got to figuring how many berries an acre would make with the plants set six feet apart, or: twelve hundred and ten plants Fer acre. The next year I planted three acles of McDonald in a solid block, but when they came to bear they did not mature a berry. Something was wrong. I soon found that this berry must be planted near some other early blooming berry to pollenate it. Most all practical fruit growers know that it wont do to plant one variety of fruit in a solid block; but I was a new beginner. I now have six acres of McDonald and Early Wonder with a few Haunt and Rog. ers that I am really proud of. I doubt if there is another six acre tract of land in this whole country that pays as well as my Early Wonders and McDonalds.

Since finding out the great value of McDonald I have been advertising it in the north. I have sold thousands of plants and root cuttings to nurserymen all over the north. It is proving hardy as far north as Illinois, and on the Atlantic coast it bids fair to proving better than any berry so far found. It is fine in Georgia. One berry planter in that state wrote me that he would set two hundred acres, or enough so, that he could ship a car load of fruit per day. McDonald is as large as the largest blackberry. The berries turn black several days before it is ripe. The berries will keep a week after being picked. This is the earliest and most productive blackberry known. I call it a blackberry, but it seems to be a cross between a blackberry and a dewberry. The vines are 
very vigorous growers. It sends up many canes from the roots that do their best when bearing time comes. Can be grown on a trellis or be kept pinched back, as the grower prefers. I keep the plants pinched back. As intimated, I am the introducer of this plant to the north, and most all nurserymen there got their original start from me. This is a berry that the man who wants to make money growing berries cannot afford to over- fruit collections. It will pay well for its room.

Prices: McDonald plants, 10ets. each; 50 cts. per dozen by mail; or $\$ 2.50$ per hundred by express; $\$ 20$ per thousand.

NOTE-The McDonald picture an pearing here is from berries grown by I'rof. L.R. Johnson, Gape Girardeau, Missouri. The cut was made by the Rural New Yorker, and shows actual size of the berries. They grow well in Missouri.

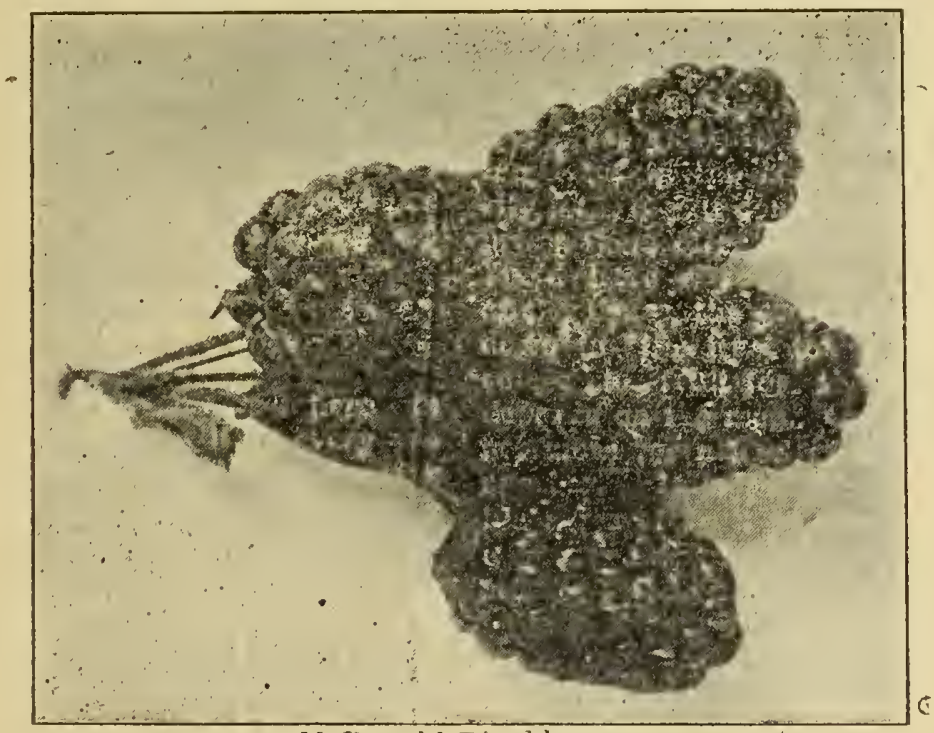

MeDonald Blackberry.

look. On the other liand, the man in town can grow a dozen plants on the back yard fence and have plenty of berries to supply his family.

If you plant McDonald berries this year you will have a prize well worth having; but be sure to mix a few Early Wonders in, as it will not bear when planted alone. and Early Wonder is needed in all

\section{Logan Borry.}

A cross between a blackberry and a raspber'y. In England this is said to be the most popular berry of all. It has the flavor of a raspberry, but the size and shape of a blackberry.

Plants, 10 cts each, $\$ 1$ jer dozen, $\$ 5$ per hundred. 


\section{Haupt Berry.}

This berry came from southern Texas. The originator claims this to be the largest, sweetest and most productive berry of all. It is 'arge enough,and,productive enough but the plants are mighty thorny. It pays better further south than 't does here.

Price, 10 cts. each, 50 cts. per dozen by mail, $\$ 2.50$ per hundred by express, $\$ 20$ per thousand.

\section{Improved Haupt.}

When the Haunt first came out there was a general mixture of plants. Some of them were entirely worthless. Among the mixup I found a plant that grew very thrifty and bore extremely large berries and lots of them. In fact it is one of the finest berries I know. I call it the Improved Haupt. It will way you to plant a few of them.

The picture on the cover of this catalog is one vine of Improved Haupt. 'This berry will of ten make five gallons of fruit to the single vine.

Price of plants $\$ 2.50$ per hundred, $\$ 20$ per thousand, or $\$ 1$ per dozert

\section{Mammoth Blackberry。}

It is truly a mammoth berry for they are an inch and a quarter lon and they are the best cooking berry I ever saw. I don't know why it is called blackberry, for its vines trail on the ground. I believe this will prove fine in dry countries, for it is a wonderful drouth resister. The canes are not thorny enough to bother, and it is fun to pick the big black fellows, Very early and productive.

Prices, 10 cts. each; $\$ 1$ per dozen; $\$ 5$, per hundred.

\section{Giant Himalaya Blackberry.}

This berry is much advertised. It is very late, and on deep sub-irs ligated land will bear often cnormous crops. Where a man wants a few plants and can water them they are fine. Can be trained in to an arbor, since the plants often make runners thirty feet long.

Price of plants $10 \mathrm{cts}$. each, $\$ 1$ per doz. by mail, or $\$ 5$ per hundred

\section{Mercerau Blackberry.}

By the time Jordan is gone we have Mercerau getting ripe. This is my last to ripen and my best late blackberry. I have later berries, but I do not regard any of them near so good to pay as Mercerau. This berry came from New York state, and I find it is very difficult to propagate, therefore I must get a good price for the plants.

Price of Plants, $10 \mathrm{cts}$. each, 50 ets. per dozen, or $\$ 2.50$ per hundred.

Early Wonder Berry.

A few year's ago I grew the Dal=

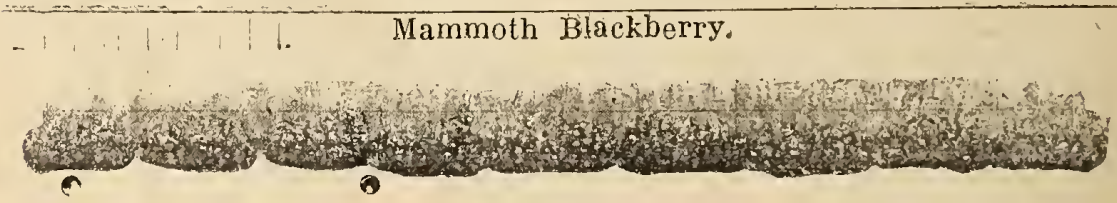




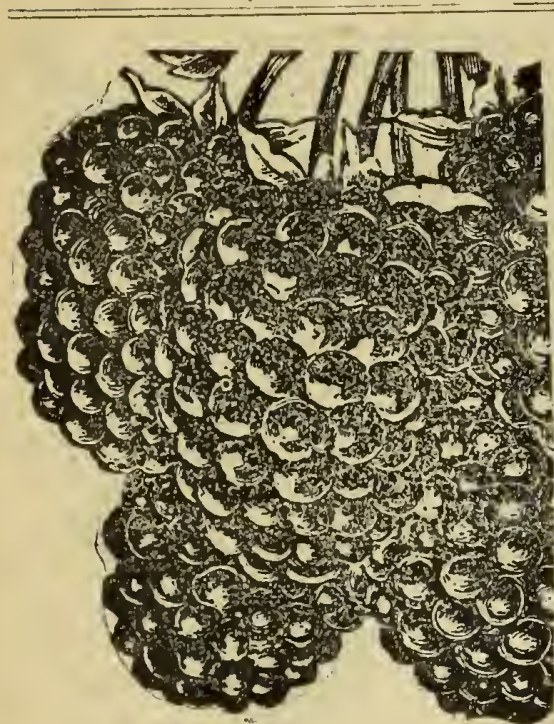

Early Wonder Blackberry.

las blackberry. It was very unsatisfactory. It did not bear enough and was too thorny. A neighbor had a berry that he said was Dallas that was fal superior to my Dallas. At last I decided to get his plants instead of the Dallas I nad. I have now been growing his herry for six years. Everybody that saw it said it was the most, wonderful producer they had ever seen. I had always been undecided as to which was the true Dallas. At last I sent to two reliable nurseries for Dallas plants and got the same kind of plants I had at first. Sio evidently my neighbor had some kind of a herry heretofore unl. nown in Texas. For want of a better name I call it Early Wonder. And it is an early wonder.

This blackberry is nearly as large as the famous Austin dewberry. It begins to get ripe when the McDonald is half gone and has ripe ber- lies for five weeks.. It is a fine combination berry with MeDonald, and will produce at least three times as many berries as the old Dallas berry. It might be called an everbearing bel'ly, for if the weather is favorable it will sometim:s rear a light crop in the fall. It has fewer leaves than any other berry I have, and is always a lelight to pickers. People who want ber'ir's for home use or to make berry juice cannot afford to overlook the Early Wonder. If you plant this berry and McDonald in combination you will have the most nroductiv: relries in the whole conntry. This rerty, will certainly give satisfaction "to any one who filants it. The seeds are very small. In fact, it is almost seedless.

I have just received a letter from New Mexico, staling that Early Wonder has a nice fall crop. A letter from Washington slate also says Early Wonder has a fine fall crop. Prices, same as AfcDonald.

\section{Austin Dewber'ry.}

The practical berry grower who grows berries to supply a home market needs fine berries from the very first of the season to the last. To supply an abundance of ber

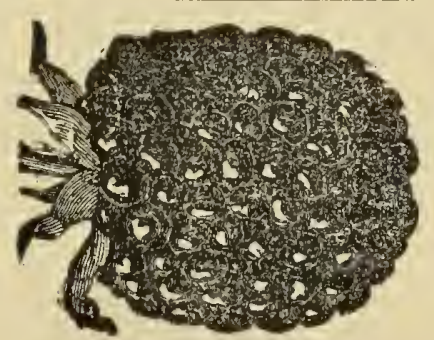

Austin Dewberry. 


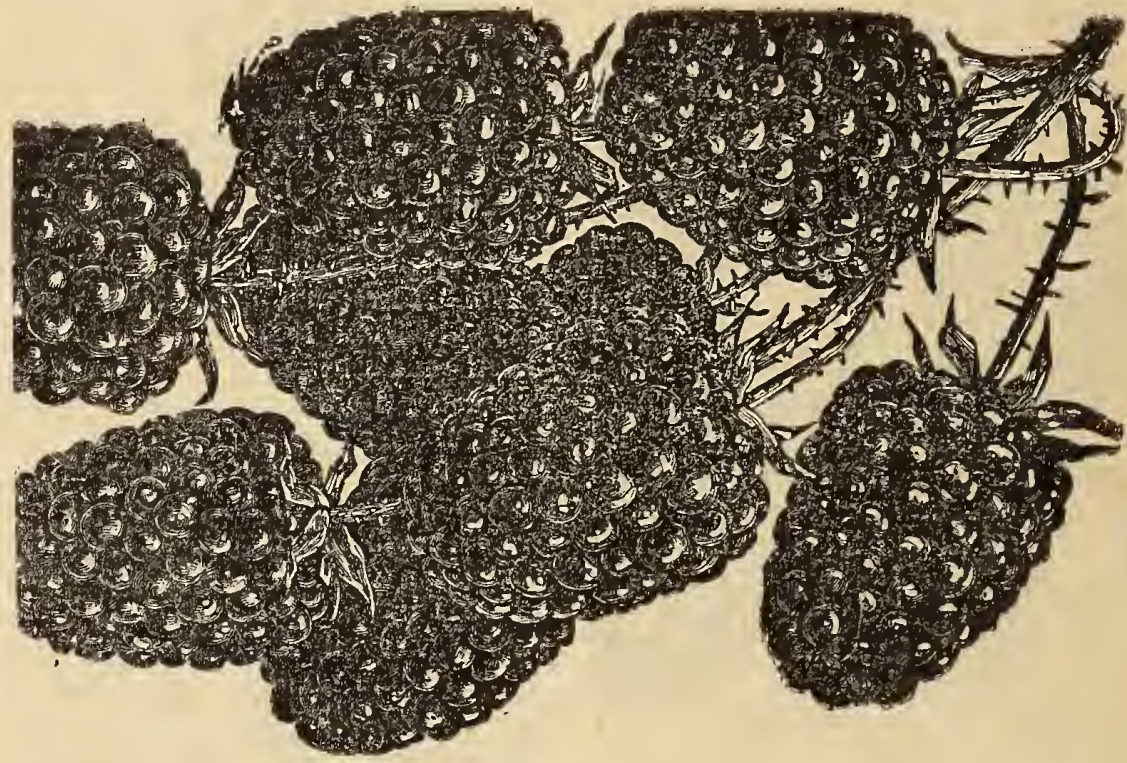

ties after Early Wonder is gone I know nothing better than the Austin dewberry. It is a true dewberry. 'The plants are fine growers and the berries are very large. I have seen Aiustin berries nearly as large as a small hen egg. In south. Texas they grow this berry to ship, but I consider it a local market herry. W. J. Shultz, a local German planter of Brown county, "Texas, says this berry never fails to cay him a hundred dollars per acre for his local market, but, of course, in our small western towns cur local markets are always limited.

Prices, 10 cts. each, 25 cts. per Hozen by maíl; $\$ 1.50$ per hundred, $\$ 10$ per thousand by express.

\section{Lucretia Dewberry.}

\section{This well known dewberry has}

never been grown much in Texas, 1 understand it does fine at clyde, but for me it is not productive enough. The berries are not so large as Austin, but sweeter.

Prices, same as Austin.

\section{Sorsiby Rlackberry.}

The Sorsby is a very vigorous grower. It is an abundant bearer, and will take the place of Early Harvest in many localities. The berries are about the size of Early Harvest, and are of very delicious quality.

Prices, 10 cts, each, 50 cts. per dozen by maíl; $\$ 2$ per hundred hy express。

\section{Jordan Blackberry، -}

This is a late blackberry that is fine to prolong the scason. It is 


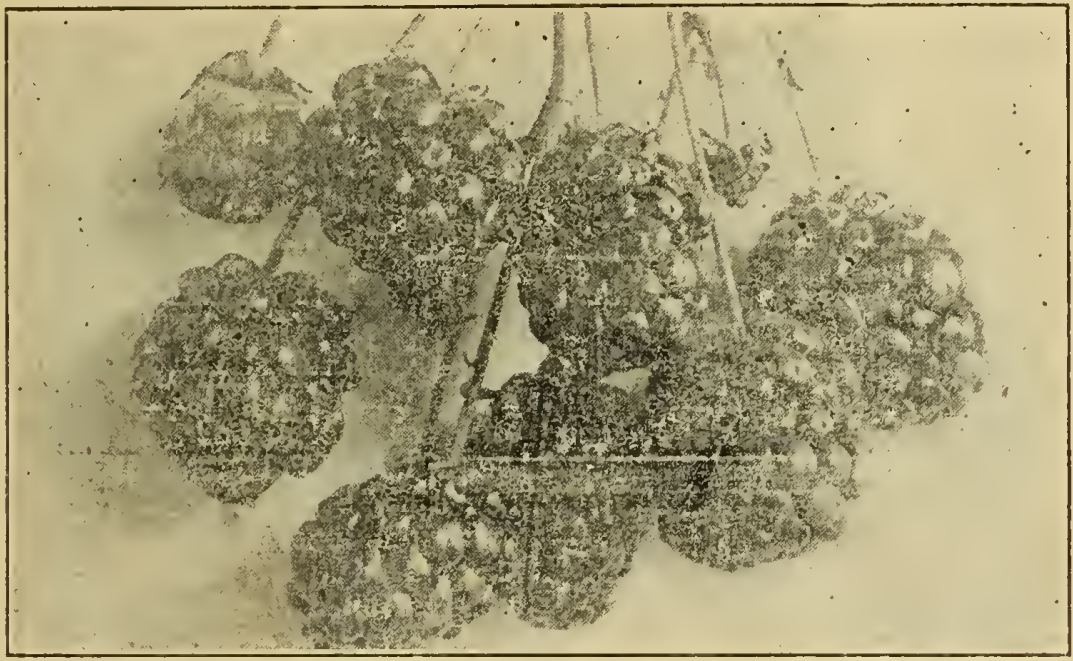

vel'y productive and is sweet as $a$ lerry can be. Here in Texas it hegins to get rine about the first of June.

Prices, 10 cts. each, 50 cts, per ciozen by mail; \$2 per hundred, or $\$ 15$ per thousand by express.

\section{Dallas Blachiberry.}

1 firm, mid-season berry. Jordarl is a better berry.

prices, Same as Jordan.

\section{Strawberries,}

lar'y Thompson and Klondike strawherry plants. These are the best strawberies we have for our couthern rlimate.

Prices, 75 cts. per liundred by mail, \$i ner thousand by express.

\section{Everbearing Strawberries.}

Where the soil is good these will bear flom May to December. The plants are very large and thrifty. They stand drouth well, but should be watered in the hot summer. We offer only superb, which is best of all.

Price, 10 cts per plant, $\$ 1$ per 25 , or $\$ 3$ per hundred.

\section{APPLE TREES.}

I have spent nearly a life time raising apples here in Erath counfy. In this time I have learned that it pays to set the kinds that will bear the quickest. There are some linds of apples that it will take the trees ten years to come into profitable bearing. I do not regard trees that it takes the best part of a man's life to bring into hearing as of much value, and especially if he can get trees that will bear in a few years. My apple trees are propagated from trees last bore in three or four years 


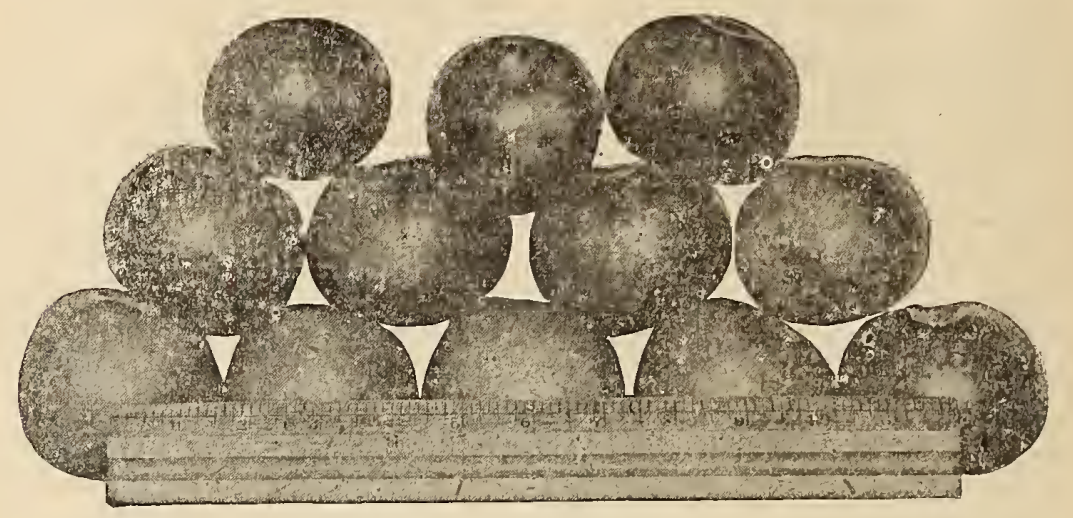

Kennard Apples.

here in my orchard. If you set trees that will bear quick you will have your money back many times over before you will get even a trop from the slow bearing kinds. Several year's ago a man planted an orchard of slow bearing irees. He waited seven years for his trees to bear and the trees never had shown a bloom. He got disgusted and dug them up. One of his neighbors had planted an orchard of the same kinds when he was thirty years old. This man had more yatience than the first one, and he got his first profitable crop when he was forty. Another neighbor planted an orcard of Delicious; Yellow, Transparent, Red June, Bannana and other early bearing varieties. The third year he had his first Banana and Yellow'ransparent. By the end of five hears he ivas selling lets of apples. By the end of ten year's he had sold enough apples to buy the other man's orchard, land and all, and have money left. Banks make money by making short loans. Mer- chants that make a success are the ones that make investments they can realize on quickly. So the olchardist that makes a big success will be the one who will plant trees that bear quickly.

Prices on apple trees: 1 to 2 foot trees, 10 cts. each,. $\$ 6$ per hundred. 2 to 3 foot trees, 15 cts, each or $\$ 12$ per hundred. 3 to 4 foot trees, $20 \mathrm{cts}$. each or $\$ 18$ per hundred. For the man planting a large orchard I regard the 2 to 3 foot trees the best of all to plant.

\section{Yelicw Transparent.}

A very large, clear yellow apple that begins to get ripe the fir'st of June. The trees are rather dwarfish growers, bul live a long time. On goorl soil they will finally malie immense, compact trees. The trees begin bearing carly, often the sicond year. The apple is a fine cooking apple and always brings a good price on the market. When you plant youl orchard be sure to include Yellow Transparent. 


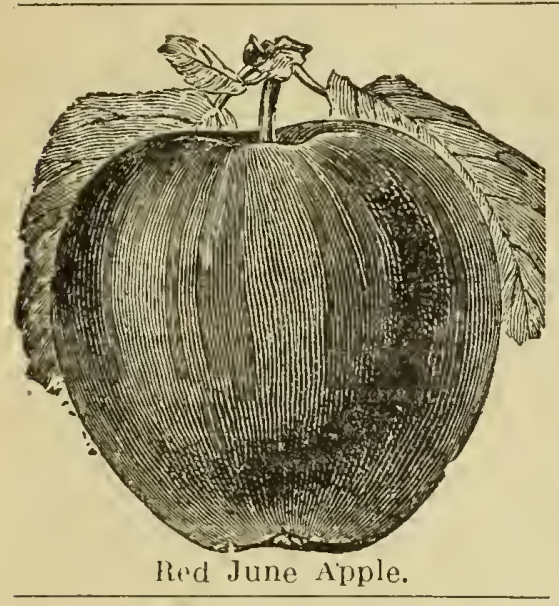

Red June.

Ai medium sized, bright red apple. Begins to get ripe along the last of June. The trees bear immense creps when they are young. 'Ilue trees grow slowly, but make large trees. We need hundreds of acres of this apple here in the south to supply the northern markets. 'Jhis apple comes in when apples are scarce in the north and it is such fine eating quality it brings the highest price. Red June apple trees usually begin bearing in three or four years. You will make no mistake to plant plenty of Red June.

\section{Sall Jacinto.}

As I write this I have four of these immense apples on my desk that weigh two and a quarter pounds. You never saw a prettier apple in your life, and you seldom sie a larger one. Here is an aplle that you just can't afford to overlook. However, I am short on traes. One of my neighbors saw these anples and bought nearly all my trees. This apple begins bearing early. It has one fault-the ciples get ripe too slowly on the trees. Price of San Jacinto, 20 cls. rachls, any size.

\section{Maiden's Blush.}

Here is a tree that will grow off lik: a weed if given half a chance and will bear quick of big yellow anjles. 'I'he apples are flat, and wiy highly perfumed. If you tithe a produce journal you will se.? inis apple quoted higher on the inarket than any other. It is a E.d one to plant.

\section{Gravestein.}

This apple makes a very large, !hrifty tree. In fact the trees Low larger than any other appla i: re I know about. The apples aro arye and flat. It can promise less and do more than any other apple. f. mes in in August. If you want a large, permanent apple tree, that will bear immense crops of big, yellow, fine tasting, good cooking apples, then plant Gravestein.

\section{Jonathan.}

This apple is so well known by all orchardists that it hardly neerls a description. However, it is at fiery red apple. 'The trees arr light colored. Bear's every year here in the south. 'The other day we picked a barlel of these anples from a seven year nld tree. They would have all graded number one.

\section{Delicious.}

This apple is now famous for its mality the world over. It makes a wirry, quick growing loee that will grow inost anywhere. These 


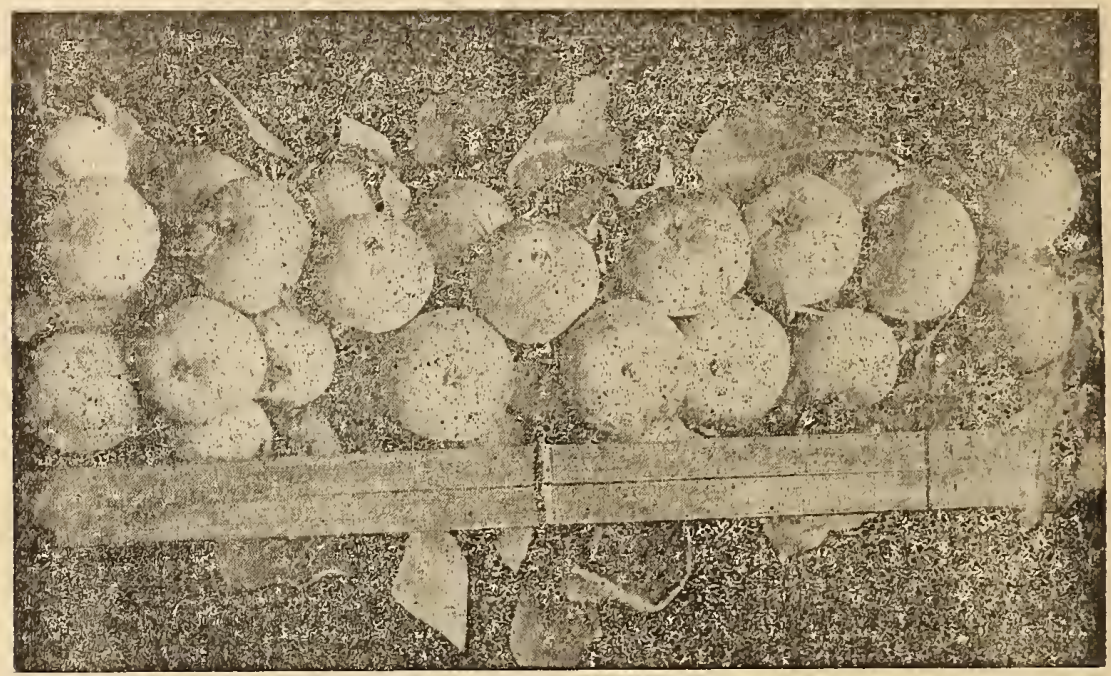

Florence Crab.

trees are inclined to be upright in growth. It comes into bearing very quickly and always bears big crops. But its crowning glory is its quality. Wherever planted it soon runs all other apples of itg season out of the market, when,people get a taste of this magnificent apple. The apples are medium sized, striped. If you have no Delicious apples in your orchard you are missing a good hing, and if you are planting an orchard be sure and do not overlook Delicious. It gets ripe in August.

Price of Delicious apple trees, 2 to 3 foot, $15 \mathrm{c}$ each, $\$ 14$ per hundred. 3 to 4 foot trees, $20 \mathrm{c}$ each, $\$ 18$ per handred.

\section{Grimes' Golden.}

An early fall apple that is very showy yellow and very fine quality. Next to Delicious in quality, and makes a very fine orchard tree.

\section{Kennard's Choice.}

The first tree of Kennards Choics is said to have been found growing wild in a thicket in Tennessee. The tree seems still to make good to grow under almost wild conditıons, for it will grow where any tree will grow. This apple is very large, flat, red. Sometimes it gets so dark colored as to be mistalien for Ark. Black. It is a very abundant bearer of high quality apples. It should be in every orchard.

\section{Wintex Banana.}

Soveral years ago we ordered three trees of this remarkable apple by mail. When they reached us they were not much larger than a lrad pencíl. We set them out and the third year after setling each tree bore several apples and have ixen bearing ever since. This is 
the apple that AndrewCarnegie paid twelve dollars a bushel for. It is a yellow apple, just the color of a banana. I believe it ivill bear mucker after being set than my rtber apple, The trees grow very rupidly.

\section{Lincoln.}

Here we have an apple that is said to do well even down on the riast. 'Thought to be a seeciling of the Rhode Island Greening. Makes siraight growing tree. The apnles are greenish colored. Gets ripe in ingust. An abundant and prompt inarer. It ought to be tried in all southern states.

\section{Wine Sap.}

A late fall apple. This apple is Father small, but it is fine quality and a sure bearer. It is well adapsed to our Texas climate, but is bet ter if planted on rather rich, moist seit. Then it is fine.

\section{Gano.}

A large, deep red apple that is very fine for market. Gano does int come into bearing until the sixthyear, but it is so fine it is worth planting.

in addition to those described we have Limber 'Twig, - Arkansas llack, Missouri Pippin, Horse and Mammoth Black Twig. These are all good apples.

\section{GRAB APPLES.}

These small apples are very fine sor preserves and jelly. After a market is established for them they certainly sell.

Prices: 2 to 3 foot trees $15 \mathrm{c}$ each \$2 per hundred; 3 to 4 foot irees, s5e each, \$15 ner hundred.

$\checkmark$ Florence; yellow striped with red. Very prolific. 'The best of all crabs.

We also have' Transcendent, very renamental. WWhitney and Mar'ha.

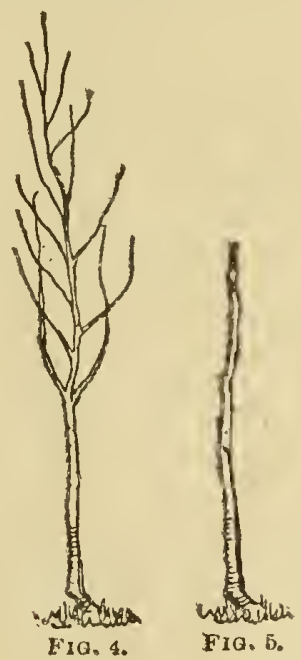

This illustration shows method of pruming after trees are sit. is a rule, trees are cut back to willin one foot or eighteen inches of the ground.

\section{SHADES.}

We have a nice stock of the following shades, ranging from one to five feet. We sell these, in order to reduce this stock, at 50 in toot. Thus a 1-foot tree will vosi 5c, a 2-foot tree, $10 \mathrm{c}$, and so un.

Umbrella Cuina.

pecan.

Wild Persimmon. 
PEACHES.

Prices; 2 to 3 foot trees, 20 cts. rach, $\$ 15$ per hundred $\$ 80$ per thousand. 3 to 4 foot trees, $25 \mathrm{cts}$. each $\$ 20$ per hundred, $\$ 100$ per thousand, 4 to 6 foot trees, 35 cts each, \$4 per dozen.

\section{Early Wheeler Peach.}

The very largest of all early peaches. Great orchards of this peacls are being planted. No peach pays better. The peach is a very large clingstone. Gets rine the middle of June. The trees are inardy and it is a sure bearer.

Fijice of trees, $35 \mathrm{c}$ each, or $\$ 30$ per hundred.

\section{Hale Peach.}

This peach is also called the Million Dollar peach. It is larger ihan Elberta, about five days later. In fact it is one of the finest of all peaches. Be sure and itant some.

Frices, small sized trees, 50 cts. earh, $\$ 10$ per hundred.

listed in order of ripening:

'Victor; early, pays ivell.

Arp Beauty; fine grower, a large yellow peach.

Carmen; best peach of its season.

Mamie Ross; June, white.

Slappy; July, large yellow.

Heath Cling, August, large white.

Henrietta; September,large yellow

Stinson; October, white.

Governor Hogg.

We can supply most any variety of peach, but the ones we list are bicst for us. We have all these nrowing in our orchard here. Hentletta and Stinson pay fine. If you jlant an orchard anywhere in rest Texas don't forget Henrietta and Stinson.

\section{PLUMS.}

Prices, 25c each, $\$ 20$ per hundred. We have every plum we list gi'uwing and fruiting in our orchard. We have several other varictres, but these we consider best to p!ant.

(jmaha; trees look like the wild plum trees that grow in the wooded sections. Plums are large and very f!nt. Gets ripe the first of September. Blooms out late. Trees grow to be large. $50 \mathrm{c}$ each, any size.

Burbank. Limbs of this plum are ofien carried around by agents to slint what wonderful bearers the trues are. A large reddish yellow ulum. Fine for cooking.

Botan; large red, sweet.

Poole's Pride. One of the best Juiv plums.

Wild Goose,

Vickson; very large, free stone ; $1 \mathrm{\Lambda m}$. In places not subject to late frost this is fine.

Nilton; early red, sure to bear. of the same character as Wild igouse.

America; large yellow, sure bearer. I believe America will bear more bushels than any other plum. liviry man planting a commercial orcliard needs America.

Cirlcien Beauty; a yellow Septemb. $i$ frim.

Irby's September. About the only difference between Irby's and Goiden Beauty is, one is red, the (ithere rellow. 


\section{THE PEAR.}

Priecs on pear trees: 2 to 3 Prol. we each, \$2.50 per dozen, \$15 [nil limulred. Large trees, 3 to 4 font inel over, $35 \mathrm{e}$ each, $\$ 3.50$ per

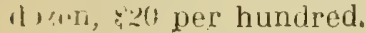

\section{Garber.}

The Garber is the earliest. The irrs grow vely fast. 'The leaves Al'f a dark green and will make is fine slade tree for any yard or twil. The fruit is large. The pear is rather flat at blossom end. 'This p'ar: wilh me begins to get ripe ibiut the first of A'ugust. The fliality is very good; and sells read iy as an eating pear. Yellow and sliowy.

\section{Keiffer.}

The heiffer near begins to ripen in sutember. It is very targe, forl must be stored before it is frond to eat. This is the great reserving pear here in Texas. Tno trces, and at least the fruit, will stand morè rough treatment than ariy olher pear. This is often called the pear of plenty, and it well deserves its name. You can plant a Keiffer pear tree in any odd place and it will always pay for its room. Mr. R. Tyndall of Clairette, Texas, has a Keiffer pear tree in a hard back yard that bear's every year. Last year this tree bore thinty bushels of as fine pears as ever grew, and bronght Mr. Tyndall $\$ 1$ per bushel. Mr.Tyndall told me of this pear himself and would not trade his tree for a good horse. If well cared for a Keiffer tree will often life fifty years. Yet you can buy a little tree almost for a song.

\section{COMPASS CHERRY.}

The only cherry that will bear in the south. I cross between at :lierry and a plum.

Price, 35e per tree.

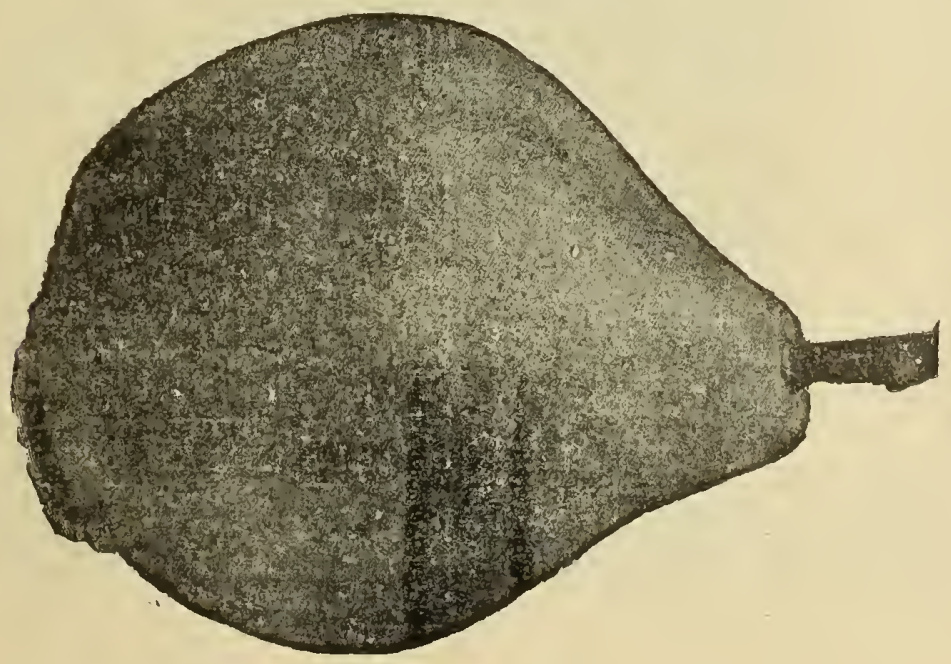




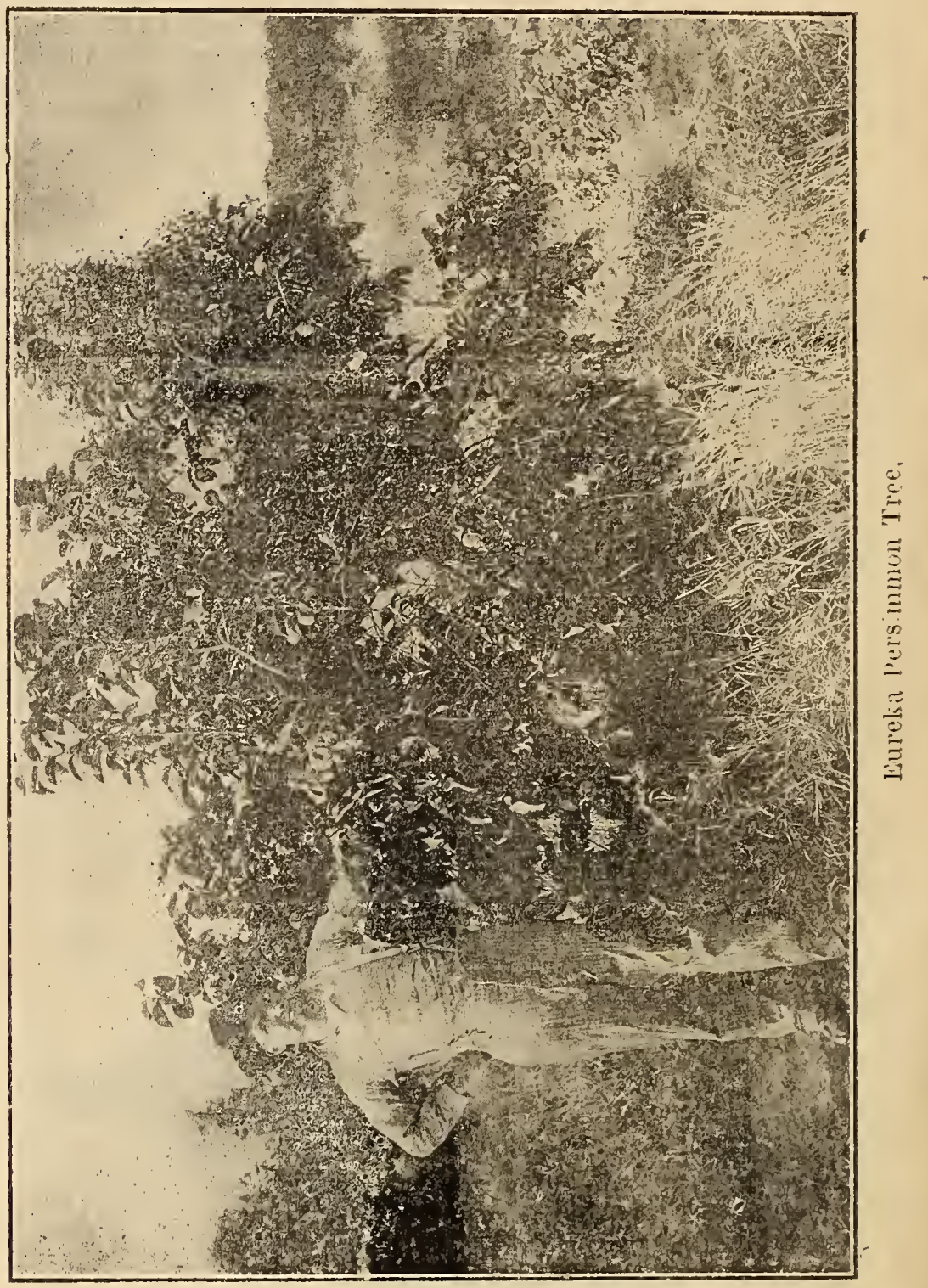




\section{PERSIMMONS.}

On my farm 1 have done a great deal of experimenting. It has always been my hobby to try all the x.ew fruits. But several years ago I found a persimmon tree that certainly goes around them all. I think more of my persimmons than of most anything else I have. But this tree in particular is something worth having. I call it the Fureka persimmon. It seems to be in some way related to the wild persimmon. At first I sold the trees at one dollar each. At that time I had very few trees to spare, But since $I$ have set an orchard of these Eureka persimmons and now have plenty of trees on hand I have reduced the price to just half.

Before it gets ripe the Eureka persimmon looks, like, a big deep yel law tomato. Some one said on seeing the,trees,full of fruit that "they looked like apples of gold." "The persimmon is yet a comparatively hew fruit. Grood ripe Japanese persimmons often sell at five cents rach. A five year old tree will often bear two hundred fruits. If no persimmon trees are planted in your country it will certainly pay you to be the first to set an orchard. We set the trees fifteen feet apart each way, or two hunrired and five trees per acre. The Fureka persimmon is hardy, and will stand almost any amount of drouth and heat. But like all other persimmon trees it appreciates good culture. Gets ripe late in the fall.

\section{Tane Nashi.}

This is a very large persimmon.
Some of them get as large as the biggest pears. It is being set jut commercially all along the coast. Next to my Eureka I regard is as the best persimmon to plant.

\section{Tamopan.}

This persimmon was brought from China by the department of agriculture. The trees grow to an immense size and one tree is said to often bear a wagon load of fruit. At this writing I have some four year old trees with very large fruit on them. They promise to be very fine. The trees are fine thrifty growers, and are said to stand the coldest weather.

\section{Da Da Maru.}

These persimmons get as big as your two fists. In fact they are the biggest of all persimmons. The quality is good.

\section{Hachia and Costata.}

These two get ripe most too early Prices on Eureka trees, $50 \mathrm{c}$ each, $\$ 35$ per hundred; 2 to 4 foot trees.

Plices on Tamopan, Tane Nashi, and Da Da Maru, 2 to 3 foot trees, $25 \mathrm{c}$ each, $\$ 20$ per hundred; 3 to 4 foot trees, 30c each, \$25 per hundred.

Japan is a small country. The land is very high in price. There fore the neople cannot afford to have a lot of trees that $h a^{\text {"e }} \mathrm{e}$ to get large before they bear. You can always count on any kind of a tree that comes from Japan bearing quickly and 'ots of fruit. This is true of the Eureka persimmon. If given good cultivation the trees 
will often bear several fruits the second year set. There are several advantages the persimmon has over other fruits. The fruits do not blow from the trees. It 4 akes a very hard hail to injure one of these persimmons when it is green. The persimmon tree is very deep rooted. They send their roots deep into the hardest soil. After the tree is once established it will live seventy-five or a hundred years.

\section{APRICOTS.}

Wi now have Apricots that bear r,aying crops.

II $r$ : $\mathrm{S}$; trees 3 to 4 foot, $25 \mathrm{c}$ eatch, $\$ 20$ per hundred.

Cluster; a sure bearer and early. INone Park; it is becoming very pepilatar.

IVe can make special prices on large (quantities! of apricots as well as peaches and plums. Write us if you,are,planting a large orchard.

\section{MULBERRIES.}

Prices; trees 4 to 5 foot, $25 \mathrm{c}$ each. Mulberries bear abundantly and are fine for chickens. There is little difference in the trees. Hicks and black English are probably the kest.

\section{California Privet.}

This plant is used more for hedges than any other plant. I have a big stock of the plants that will neasure about two feet high. I sell them at such a low price any one can afford a hedge. My mail, $\$ 5$ per hundred. By express $\$ 3$ per hundred.

\section{THE FIG.}

Price. Fig trees, 35c each, 10 for $\$ 3, \$ 20$ per hundred.

It has long been thought that fig's could not be raised in this jart of Texas, but it has now been found that they could be raised as far north as New York. I have two acres of figs. 'There are no two acres on my plice that pay better. have my fig plants set twelve feet apart each way. Each nlant makes trom one to two gallons of figs a year." I have more than three hundred plants to the acre, and as figs sell readily at 40 ets. per gallon, they pay pretty well. They are rasily cultivated and are à sure crop. But it must be remembered that my figs frost bite down to the ground every year" and sprout up from the ground to bear. If they are given some winter protection so the plants will not winter kill the above yield can be doubled. My fig plants will bear the first year after being set.

\section{Magnolia.}

4 rapid growing forked leaf fig. New set plants will bear the first year set. Figs are large, straw colored. This as well as my other yalieties will make a most delightful frot or house plant in the north. If set in the garden and given some winter protection they will bear fine crops of figs that will be a delight to the grower and a curiosity to all who see them.

\section{Ischia.}

A rigorous growing fig. Ornamental. The fruit is light green out- 
side and right bright red inside. It hiss a delicious sweetness hard to describe.

\section{Brunstüick.}

Trees fast growing. Leaves large, trnamental. A lárge black fig. Grws aboout as large as an ordinaly hen egg.

\section{Jixtu Japan.}

This is a dwarfish growing fig. Makes a fine pot plant. Figs are rather small, dark brown. This is it very abundant bearing fig The little trees not over six inches in height will begin bearing.

The fig is mildly laxative. 'The frover can get, almost any price for fresh figs, Eat figs and throw pliysic to the dogs.

If you live in town and have only a small lot, plant a few grape vines, a dozen McDonald and Early Wonder berries and two or three fig trees. If the soil is good plant three or four persimmon trees. They will grow in a very small space and you will have one of the most ornamental trees you "ver saw. The finest peaches ever grown in Erath county. were grown in a șmall back yard, where the ground. was nearly as hard as a brick. The apricot makes a fine back yard tree; It delights in hard snil, and bears big crops some years.

\section{ALTHAEAS.}

This is one of the prettiest of all fiowering shrubs. Stands much nee lect and drouth. We have pink anc white. Price 25c each.

\section{THE PECAN.}

The pecan tree will live on and on for hundreds of years. At first I was "sorter juberous" about plant ing this tree on our sandy uplands. But I Now have Stewart pecan trees twenty-five feet high and as healthy as pecan trees can be. Pecans are hard to propagate, and after they are propagated they are hard to dig up, but when you plant one and get it started you have a tree that will be as ncar a permanent thing' as a'railroad. One man in this country.has a pecan treo that pays him sixty dollars per year, and has been paying him this for years. I hear of others even better: Plant. a few trees and watch them grow. They will bo a comfort in your. old age. My trees are grafted and budded from my bearing trees.

Prices; 1 to 2 feet $75 \mathrm{c}$ each, $\$ 6$ for ten, $\$ 50$ per hundred. 3 to 4 foot trees, $90 \mathrm{c}$ each, $\$ 7.50$ for ten,

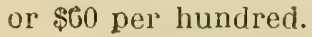

\section{Stewart Pecan.}

A very large nut; a little dark sliell. This is the best of all pecan: to plant where land is to be cultivated. In fact I doubt that there is a better pecan. Trees bear earIy - The trees have lery large leaf, sind are the most ormamental of all trees. If you are in doubt as 10 whät pecan to plant plant Stewartis.

\section{Halbert Pecan.}

Originated in west Texas. Do not plant this pecan where the land is to be cultivated. 


\section{GRAPES.}

On grape plants I defy competition. My soil seems admirably alapted to the grape. In one year I can grow vines that are as large is vines usually sold for two, year old vines. If you want grape vines that are strong, well rooted; in fact perfect in every way try a fêw of my vines.

Delaware. The first grape to ripen. Said to be the finest quality of all grapes. Small red.

Concord. The old stand-by black grape. You can depend on Concord.

Niagara. A large white grape.

Herbemont. Small brown grape. Very fine quality. Makes a very large vine. Sometimes sold as an arbor grape.

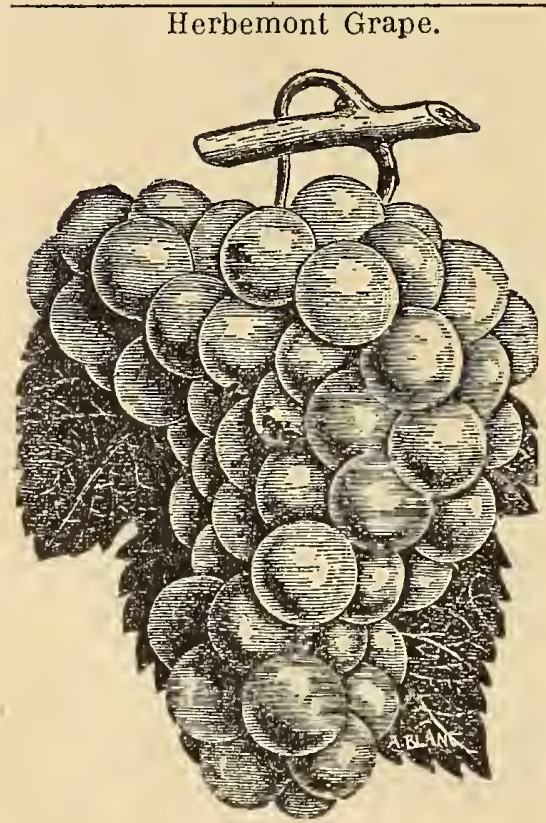

Calawba. Catawba is a very fine large red graps. Ripens rather late, or mid-seasor.

Carmen. In Carmen we have one of the finest grapes that can be grown. The vines are very vigorous growers. When it comes to bearing no grape can beat Carmen. The clusters are very large, often weighing two pounds. The grapes are black, medium size and do not shell from the bunch. This grape gets black midseason but will hang to the vines until late fall, getting better all the time. Price $20 \mathrm{c}$ each. $\$ 15$ per hundred.

Fern and Munich. Both these grapes are similar to Carmen, but later. For quality I doubt that any is finer than Munich. Every grape grower, especially in the south, should have plenty of Fern, Garmen and Munich.

Marguerite. A very late fall grape that should be in all collections.

Prices on grapes by mail, 15 et.s. each, ten for $\$ 1.25$. \$10 per hundred. By express, 10 cts. each, ten for 75 cts. $\$ 8$ per hundred.

Mustang; for arbors. Will stand any kind of drouth; will grow to the top of the highest trees. I have seen vines a hundred yards long on wire fences. I defy anyone to find a vine that is finer for arbor's than the Mustang. Good for park planting. Fruit, green, is very fine for jelly, and when ripe inakes very good wine. Grows very rapidly in any kind of soil. If it is a vine you are looking for here it is. Worth all other ornamental vines put together.

Tines 25 cts. each. 


\section{SPECIAL OFFERS.}

\section{Special Number One.}

For $\$ 1$ we will mail you three Austin dewberry plants, three McDonald, three Early Wonders, three Rogers, three Jordan and three Haunt. This will give you a chance to plant some of the best berries.

\section{Special Number Two.}

For $\$ 1$ we will mail you three Wine Sap apple trees, three Lincoln, three Jonathan and three kennards. Just right for a small orchard.

\section{Special Number Three.}

For $\$ 1$ we will mail you three Niagara grapes, two Concord, three Magnolia figs, and one Ischia fig.

You can have your own vines and fig trees for a very small price.

\section{Special Number Four.}

Three to four foot trees: three Victor, three Mamie Ross, three Carmen, three Henrictta and two Stinson; a whole peach orchard for only $\$ 3$. By express.

\section{Speeial Number Five.}

Three to four foot trees: three Red June, three Transparent, six Jonathan, four San Jacinto, four Kennards and four Wine Sap, all for $\$ 3$. This will make a nice famity apple orchard. By express.

\section{Special Number Six.}

Two Burbank, two Botan, two Shiro, tivo Omaha, two Golden Beauty and two Milton plums, all for: $\$ 3$.

\section{Special Number Seven.}

Four Keiffer, four,Garber pears; one Yemon, one Hyakume, one 'Tune "ashị and one Eureka persimmon, All for $\$ 3$.
Special Bargain Lot.

Trees by mail. Twelve apple trees year old, thrifty, well rooted, easy to transplant. Your selection of the following by mail, post paid.

Red June, Early Harvest, San Jarinto, Maiden's Blush, Wealthy, Deiicious, Jonathan, Wine San, Ben Davis, Kennard, Banana and Shockly. Twelve of these, your selection, delivered at your door by mail for only $\$ 1$.

\section{ROSES.}

Our roses are the finest fieldgrown plants. They will begin blooming almost immediately after being set.

$W_{B}$ have pink and white Killarny, Marchiel Neil, Etoile de

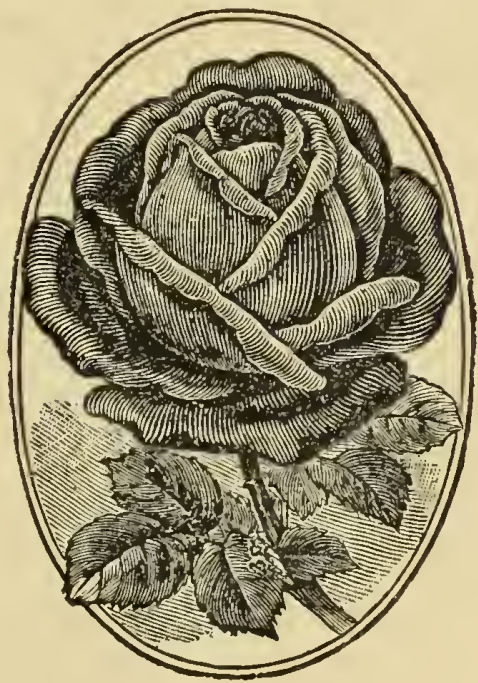

France, Augusta Victoria, Dorothy Perkins and others. In fact, we have all the leading roses. By mail, 35 cts. each $B y$ express 25 cts.each 


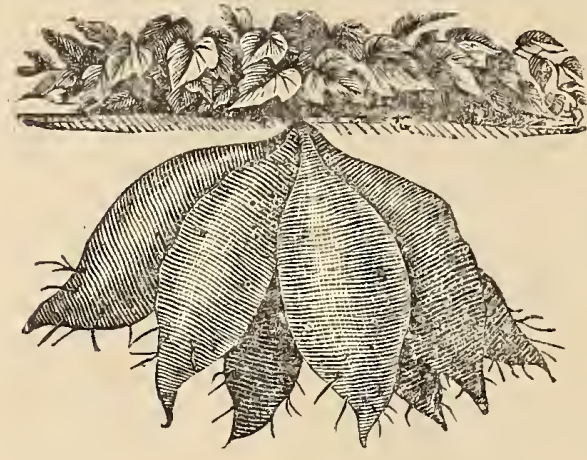

SWEET POTATOES.

We can supply the following varieties of sweet potato. plants. Good count and safe arrival guarinteed.

This has been a leading truck rop with me for the past several years. I have tried all kinds, but for high yields and earliness I find none to beat the Triumph. This potato makes a very vigorous vine that smothers grass and weeds. 'ithe potatoes are white, and here in the south do not sell as well as the pumpkin yam, but they are so early that you can sell potatoes six weeks before the man who raises pumpkin yams has any. This potato is the best keeper of all, and by keeping dry can be kept until new potatoes come in each spring. Triumph holds the record of the largest yielding potato known.,Last. season I raised a hundred bushels from a quarter of an acre. At this writing I have a patch that promises to beat this yield a city block. This is the potato for the man who wants to sell potatoes early. In quality the potato is mealy, and cooks quickly. It is fine eating when potatoes are scarce, and good when they are plenty. This is a fine potato for the northern grower-it makes so quickly.

Prices of potatoes f.o.b. here $\$ 2$ per bushel.

We will have plants in May, and maybe some in April.

Price of plants, $\$ 2.50$ per thousand.

We will also have Nancy Hall and Porto Rico potatoes at the same prices as Triumph.

\section{Porto Rico Yams.}

This is the most popular potato in the eastern states. The skin is Jeep yellow, almost red. Flesh is as yellow as gold. The vines grow very vigorously.

Fomato, Peppor and Cabbage Planis

I grow thousands of these plants each year and will have the leading varieties, and plenty of Dwarf Champion, McGee, etc.

Price, 50 cts. per hundred by mail or $\$ 2$ per thousand by express. You pay express.

We want the plants we sell you to be sure and grow. Your success means our success, and for that reason we agree to replace all that die within one year at half price. But we hope you will lake good care of your trees and not lose many of them, for your loss means our loss. If they ale damaged when you get them from the railroad be sure and notify us at once and we will talie the matter up with the company. Remember, we waive all responsibility if you do not notify us at once; but if rotified within five days we will replace the shipment. 


\section{ARBORTITAES.}

It has always been considered $f$ it the arborvitae is the most difliu ult of all vlants to transplant. If n; roots are never allowed to get w. ianied as peaches or apples. I will take special pains in digging t'ipse. Wve will keen the roots from (:xposure at all times and pack,well. Nevex unwrap them until ready to set. Then see that the roots are not exposed a minute to the air. I liave the Rosedal', the preltiest of all arborvitaes. By mail, $10 \mathrm{cts}$. each; $25 \mathrm{cts}$. each by express.

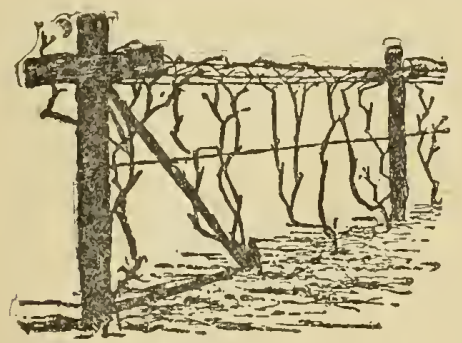

The illustration shows one of the west methorls of training grapes.

\section{Asparagus Roots.}

Birr's Mammoth, Conover, Palmetto and Colosal asparagus. 50 cts. per. hundrert, or $\$ 3$ per thousand.

\section{Bocliy Ford Cantaloupe Seed.}

We have several pounds of this ared saved from the biggest crop "f melons we ever raised. They are well matured seed, and sure i.) give a good stanil. Per ounce, io cts. Quarter pound. 25 cts. or !wind, 75 cts. by mail.
SPANISH PEANUTS.

The Spanish peanut is the hardirst of all peanuts, being a great drouth resister. In the past two years this peanut has become almost, if not quite, the most staple of all crops. The will often produce a hundred bushels per acre.

Prices on seed nuts: $\$ 2$ per bushel, ten bushels for $\$ 17.50$

\section{Olira Secd.}

$i$ is peculiar, but okra seed are the most difficult to set irue to name. For several years I had bren ordering White Velvet okra but only recently got the serd tiue to name. As a vegetable okra is one of the best crops a market miner can porduce, and the genuirs White Velvet will make twice is much as any other kind. I have sived several bushels of seed from my market garden and can offer rigriet gardener's genuine White irvet. This okra is very early and the pods stay tender for quite a while. If you are going to plant rhra it will pay you to get the amuine White Velvet. Price of seed: Small packet 5 cts; ounce 10 cts; pound 50 cts.

We begin shipning about Noremlor 15, and continue to ship berry rmes until April 1. Trees are best planted during November, Deeemher, Jannary and February. 
III:cec Berries and Fruit Trees Will Do Well.

Every year I get letter's from [ur.p? asking, "Do I reckon berrie's will do well with them?" They say' "that no one raises them in their country." I wish to state that the blackberry will grow well on l:ust any kind of good corn, oat or colten land. If no one raises ber. lifs ishere you live, this is a good reas'mll why you ought to give then a trial. An old man once gave me this advice. He said, "Joe, don't $n \rightarrow v, \Gamma$ waste your time trying to fisure out why a black hen lays a whit, erg, but get the egg." 'I'he thing to do is give them a trial. (iat the egg before the other felin, even finds the nest.

I'werity five years ago Capt. J. R. Eilis, our pioneer apple grower uf tills country decided he would recw apples. He ordered several hinmcired trees and set them out. His neighbors thought it was funny fur a man to be trying to grow olupes this far south. But when Mr. Ellis' apple orchard got to troaring people went twenty miles tc see it and buy apples from Mr. Fillis. Capt. Ellis has made a fortune from his orchard. He got the eggs before the other fellow even found the nest.

Not only this, but Capt. Ellis has come very near finding the fountain of youth; for he is one of the youngest old men I ever saw He can do as much work as a young man. Fruit growing is his hobby, and he has no time to think of growing old.

Men who have such pleasant hobbies as growing fine fruit do not set old as fast as men who have nothing to do but count their monoy and whittle goods boxes.
I like to visit Mr. Ellis and his orchard. Though he has 1,000 , he knows the name of every tree by the color of its bark. He can tell you when each tree was set, its fruit record, and whether it bear's paying crops or not.

Such men as Ellis are the ones who get the most pleasure out of life.

Several years ago I was peddling blackberries from a small spring Wagir on the streets of Stephenvilin. A man came along on a load of nay with four mules to his wauon. He was away up in the air, and iooked down on me and askerl if "! didn't have mighty little to du?" I probably sold my load of berries that day for nearly as mueh as the man got for his big load of hay, and I had loads of fruit for many days to come. If you can ruab it a rule to sell as much as ten dollars' worth of fruit each day for six months out of the yea: you will beat a hundred acre liay farm; and you can raise the frut or five or ten acres.

Great things are made up of many small things. Even the mighty clouds that pass over the aarth are made up of many small drops of rain. When you start to market if you load your wagon with many small things, all taken ogether may some day amount to enough to buy a farm or an automobile. A few gallons of berries, a bushel or two of apples or pears, a few plums, taken to town when you go will pay expenses. If vou have no time to plant a berry patch let your wife plant one. Maybe when she sells enough berries to buy an auto she will let you ride in it occasionally. 

